\title{
STUDI LITERATUR PENGARUH MUSIK INSTRUMENTALTERHADAP KONDISI BURNOUT SYNDROME PADA DOSEN PERGURUAN TINGGI
}

\section{Magdalena Florensia Susanto, Dewi Retno Suminar}

Fakultas Psikologi, Universitas Airlangga, Indonesia.

Email: magdalena.florensia.susanto-2018@psikologi.unair.ac.id,

dewi.suminar@psikologi.unair.ac.id

\begin{abstract}
Abstrak
Berdasarkan tingkat pendidikan, beberapa penelitian menemukan bahwa semakin tinggi tingkat pendidikan, semakin tinggi tingkat burnout. Hal ini dimungkinkan karena seseorang dengan tingkat pendidikan yang lebih tinggi, bekerja dengan tanggung jawab yang lebih besardan tingkat stress yang tinggi. Penelitian ini bertujuan untuk memperoleh gambaran yang mengenai pengaruh musikinstrumental dan stress kerja terhadap kondisi Burnout Syndrome dosen perguruan tinggi baik negeri maupun swasta. Penelitian ini menggunakan metode studi literatur pada basis data elektronik, seperti: Educational Administration Quarterly Journal, Research in Education, Active Learning in Higher Education SAGE Journals, JurnalPsikologi Indonesia, Jurnal Psikologi Undip, Jurnal Psikologi Teori dan Terapan, Jurnal Sains Psikologi, Jurnal Psikologi Ilmiah, Jurnal Intervensi Psikologi, Jurnal Pemikiran dan Penelitian Psikologi, Jurnal Psikostudia Universitas Mulawarman, Jurnal Magister Psikologi UMA, Psychopolytan dari tahun 2003-2019. Beberapa penelitian membahas burnout yang ditinjau dari faktor faktor lain dukungan sosial, selfefficacy, konsep diri, regulasi diri, kebersyukuran, identitas profesional, tekanan hidup, dimensi kepribadian constiousness, ambiguitas peran, dan beban kerja.
\end{abstract}

Kata Kunci: Burnout, Musik Instrumental, Dosen

\section{Abstract}

Based on education level, several studies have found that the higher the level of education, the higher the burnout rate. This is possible because someone with a higher level of education, works with greater responsibility and a high level of stress. This study aims to obtain an overview of the influence of instrumental music and work stress on the Burnout Syndrome condition of university lecturers, both public and private. This research uses literature study methods on electronic databases, such as: Educational Administration Quarterly Journal, Research in Education, Active Learning in Higher Education SAGE Journals, Indonesian Psychology Journal, Undip Psychology Journal, Theoretical and Applied Psychology Journal, Psychology Science Journal, Psychology Journal Scientific, Interventional Psychology Journal, Psychological Research and Thought Journal, Mulawarman University Psychostudia Journal, UMA Psychology Masters Journal, Psychopoly Tan from 2003-2019. Several studies discuss burnout in terms of other factors, 
social support, self-efficacy, self-concept, self-regulation, gratitude, professional identity, life pressure, consciousness personality dimensions, role ambiguity, and workload.

Keywords: Burnout, Instrumental Music; Dosen

Diserahkan: 03-01-2022Ｄiterima: 25-01-2022Ｄiterbitkan: 20-02-2022

\section{Pendahuluan}

Definisi dosen Menurut Undang-Undang Republik Indonesia Nomor 14 Tahun 2005 adalah pendidik profesional dan ilmuwan dengan tugas utama mentransformasikan, mengembangkan, dan menyebarluaskan ilmu pengetahuan, teknologi, dan seni melalui pendidikan, penelitian, dan pengabdian kepada masyarakat. Semakin dosen berkompeten maka akan semakin berkualitas lulusanlulusan yang dapat dicetak, dan semakin bermutu kualitas pendidikan di Indonesia. Kompetensi yang dimiliki dosen juga akan menentukan karir dosen itu sendiri. Hal ini membuat dosen dituntut untuk selalu meningkatkan kompetensi untuk melaksanakan tugas dan tanggung jawabnya. Kemampuan individu untuk melaksanakan tugas dan tanggung jawab merupakan hal yang penting bagi kesuksesan karirnya, namun jika tugas dan tanggung jawab yang dipikulnya dirasa terlalu berat maka dapat menimbulkan stress pada individu yang bersangkutan (Cahyolaksono, 2008).

Stres kerja dapat memberikan dampak negatif pada diri seseorang seperti perasaan bosan, kurang bersemangat dalam bekerja, peningkatan ketidakhadiran kerja, penurunan produktivitas kerja, dan seseorang yang bekerja di bidang pengajaran, baik guru atau dosen pada dasarnya merupakan bagian dari bentuk pekerjaan yang sangat rentan terhadap burnout (Hakanen, etal., 2006).

Menurut Kreitner dan Kinicki (2004) salah satu dampak dari stress kerja yang berkepanjangan akan menyebabkan seorang individu mengalami burnout. Burke (2000) menyebutkan bahwa burnout merupakan proses psikologis yang dihasilkan oleh stres pekerjaan yang tidak terlepaskan dan menghasilkan kelelahan emosi, perubahan kepribadian, dan perasaan pencapaian yang menurun. Dengan demikian, orang-orang yang burnout mengalami kelelahan secara emosional, fisik, dan spiritual (Maslach dan Leiter, 1997). Berdasarkan tingkat pendidikan, beberapa penelitian menemukan bahwa semakin tinggi tingkat pendidikan, semakin tinggi tingkat burnout. Hal ini dimungkinkan karena seseorang dengan tingkat pendidikan yang lebih tinggi, bekerja dengan tanggung jawab yang lebih besar dan tingkat stress yang tinggi. Dimungkinkan juga bahwa orang yang berpendidikan tinggi memiliki ekspektasi yang lebih tinggi terhadap pekerjaannya dan mereka menjadi lebih tertekan saat ekspektasi tidak terealisasi (Maslach, et al, 2001).

Maslach menjelaskan burnout adalah stress yang dialami individu dimana pekerjaannya berhadapan secara langsung dengan manusia sebagai penerima pelayanan. Dosen selaku civitas akademika dalam setiap aktivitasnya pasti akan mengadakan kontak langsung dengan individu-individu lain, seperti dalam bentuk 
pertemuan rapat secara periodik dengan atasannya, hubungan rekan kerja dengan sesama dosen dan staf administasi secara rutin maupun interaksi antara dosen dengan mahasiswa dalam bentuk perkuliahan, seminar, bimbingan dan hubungan dalam bentuk lainnya (Maslach, 2001). Pada penelitian sebelumnya dikatakan bahwa karyawan yang baru bekerja akan lebih cenderung untuk mengalami burnout daripada karyawan yang sudah bekerja dalam waktu yang lama.

Beberapa hasil penelitian terdahulu menunjukkan bahwa stres di universitas merupakan masalah yang mengkhawatirkan. Ditemukan bahwa sekitar $40 \%$ dari $20 \%$ dari 1.086 karyawan mengalami tekanan psikologis yang tinggi di Universitas Quebec (Biron, 2008). Sebuah penelitian pada karyawan universitas di Australia tahun 2000 menemukan bahwa baikstaf umum maupun staf akademik mengalami peningkatan stres dalam 5 tahun terakhir, dengan staf akademik mengalami tingkat stres yang lebih tinggi dibandingkan dengan staf umum (Winefield, 2002).

Fenomena stres kerja di perguruan tinggi juga terjadi di Indonesia. Beberapa penelitian terdahulu mengenai stres kerja menemukan bahwa rata-rata stres kerja staf akademik di Akademi Kedosenan (Akper) Sorong adalah menengah sebesar 56,72\% (Badra, 2004). Selain itu, penelitian lain menemukan bahwa 24.000 (30,27\%) dari 80.000 guru mengalami stres kerja berat (Safaria,2011). Penelitian terdahulu yang dilakukan oleh Sri Wayanti dkk. juga membuktikan bahwa burnout dialami oleh para dosen dengan persentase 50\% kelelahan secara fisik dan 56,3\% mengalami kelelahan emosianal yang tinggi (Wayanti,2016).

Karena itu penting untuk dilakukan penanganan stress kerja dan burnout pada dosen, salah satunya adalah berupa terapi musik. Terapi musik berperan sebagai salah satu teknik relaksasi untuk memperbaiki, memelihara, mengembangkan mental, fisik, dan kesehatan emosi (Djohan, 2006). Hasil penelitian dalam jurnal Labbe et al. (2007), yang berjudul "Coping with Stress: The Effectiveness of Different Types Of Music", menyebutkan bahwa mendengarkan musik klasik yang santai akan menghasilkan penurunan yang signifikan dalam kecemasan, kemarahan, dan gairah sistem saraf simpatik, dan meningkatkan relaksasi dibandingkan dengan mereka yang duduk diam atau mendengarkan musik mental berat. Musik secara luas juga digunakan untuk meningkatkan kesejahteraan, mengurangi stres, dan mengalihkan perhatian individu dari gejala yang tidak menyenangkan yang dikutip dari artikel berjudul "Music as Therapy" (Kemper, 2005).

\section{Metode Penelitian}

Metode yang digunakan pada penelitian ini adalah studi literatur berjenis descriptive review. Adapun metode jenis ini digunakan peneliti untuk memperoleh data dan informasi yang dapat membantu peneliti dalam melakukan identifikasi dan interpretasi temuan untuk menjawab research question (Grant, Dore, Bates, \& Justice, 2009). Data-data temuan yang digunakan merupakan data sekunder berupa jurnal maupun artikel internasional. Basis data elektronik internasional yang digunakan, antara lain: : Educational Administration Quarterly Journal, Research in Education, 
Active Learning in Higher Education SAGE Journals, Persona (Jurnal Psikologi Indonesia), Jurnal Psikologi Undip, Jurnal Psikologi Teori dan Terapan, Jurnal Sains Psikologi, Intuisi : Jurnal Psikologi Ilmiah, Jurnal Intervensi Psikologi, Jurnal Pemikiran dan Penelitian Psikologi, Jurnal Psikostudia Universitas Mulawarman, Jurnal Magister Psikologi UMA, Psychopolytan (Jurnal Psikologi) dan Google Scholars.

Pencarian jurnal telah dilakukan sejak 20 Oktober 2020 hingga 4 Januari 2021 guna menemukan jurnal yang sesuai dengan kajian penelitian. Peneliti setidaknya telah menemukan 20 jurnal penelitian nasional dan internasional dalam kurun waktu publikasi dari tahun 2003 hingga 2019. Strategi yang digunakan peneliti dalam pencarian berbagai literatur internasional tersebut adalah dengan menggunakan sejumlah kata kunci yang mengerucut pada fokus kajian penelitian, yakni: burnout, stress kerja, musik instrumental, kelelahan kerja

,terapi musik, kejenuhan, beban kerja.

\section{Hasil dan Pembahasan}

Berdasarkan proses seleksi terhadap jurnal yang telah diakukan oleh peneliti, diperoleh10 jurnal terpilih yang disajikan datanya pada Tabel 1. Dengan keterangan sebagai berikut :

- RQ : Research Question (pertanyaan penelitian) sebagai acuan dari proses pencarian literatur

- Y : Tanda bahwa informasi atau data mengenai RQ ada di dalam jurnal tersebut dan dapat digunakan dalam penelitian

- $\quad \mathrm{X}$ : Tanda bahwa informasi atau data mengenai RQ tidak ada di dalam jurnal tersebut dan tidak digunakan dalam penelitian

Berdasarkan tabel diatas, diketahui bahwa terdapat 2 jurnal tahun 2014, 2 jurnal tahun 2015, 2 jurnal tahun 2016, 1 jurnal tahun 2017, 1 jurnal tahun 2018, 2 jurnal tahun 2019. Mengingat konteks burnout yang ingin diangkat adalah pada pengajar atau dosen di Indonesia maka hanya terdapat 1 jurnal bahasa Inggris dan 9 jurnal bahasa Indonesia. Kesepuluh jurnal tersebut menyebutkan berbagai macam faktor yang dapat mempengaruhi kondisi burnout dan hanya 1 jurnal yang membahas mendalam tentang bagaimana cara kerja musik sehingga dapat menurunkan tingkat stress seseorang.

\section{Hasil Analisis Pengaruh Musik Terhadap Stress Kerja dan Burnout (RQ 1)}

Pada Jurnal no. 4 yang berjudul "Musik Kejien Dalam Menurunkan Tingkat Kecemasan, Stres, dan Depresi" memiliki variabel independen Musik Keijen dan variable dependen yaitu Kecemasan, Stress, Depresi. Hasil penelitian ini membuktikan bahwa terdapat penurunan tingkat kecemasan, stres, dan depresi pada mahasiswa Jurusan Teknik Elektro Politeknik Negeri Samarinda setelah diberikan terapi musik Kejien. Namun, tidak ada penurunan penurunan tingkat kecemasan, stres, dan depresi pada mahasiswa Jurusan Teknik Elektro Politeknik Negeri Samarinda setelah 
diberikan terapi musik Mozart. Berdasarkan penemuan jurnal ini, maka analisis lebih lanjut yang dilakukan oleh penulis adalah sebagai berikut.

Menurut Lazarus \& Folkman (dalam Morgan, 1989) stres adalah keadaan internal yang dapat diakibatkan oleh tuntutan fisik dari tubuh (kondisi penyakit, latihan, dan lain-lain) atau oleh kondisi lingkungan dan sosial yang dinilai potensial membahayakan, tidak terkendali atau melebihi kemampuan individu untuk melakukan coping. Stres dapat mempengaruhi kesehatan baik dari segi fisik, maupun segi psikis. Stres yang tidak mampu dikendalikan dan diatasi oleh setiap individu akan memunculkan dampak negatif, danbila dibiarkan berlarut-larut individu yang memiliki tingkat stres yang tinggi dapat menjadi depresi. Jika stress berada pada konteks stress karena pekerjaan, maka stress tersebut merupakan salah satu faktor penyebab sering terjadinya kondisi burnout pada individu.

Distress menunjukkan tingginya tingkat stres yang memiliki akibat negatif, sedangkan eustress menunjukkan tingkat stres yang cukup rendah yang dibutuhkan untuk menggerakkan orang-orang dalam hidupnya. Stres pada waktu kerja dan dalam kehidupan sehari-hari tidak bisa dihindarkan. Beberapa individu tidak dapat menguasai atas suatu periode waktu karena stres kerja. Ketika individu menjadi letih dan merasa bahwa tidak ada sesuatu yang positif dikerjakannya, mereka menunjukkan sebuah gejala yang sering disebut dengan burnout. Gejala burnout dapat dialami setiap orang atau pekerja. Perasaan kesal-marah didefinisikan sebagai suatu proses psikologis yang disebabkan oleh stres kerja secara terus menerus yang mengakibatkan keletihan di antara pekerja dan menimbulkan kepuasan kerja yang rendah. Dapat dikatakan bahwa semakin tinggi tingkat stress individu, maka semakin tinggi tingkat resiko terjadinya burnout (Baron \& Greenberg, 1990).

Menurut Anastasi (1990) untuk mengurangi stress kerja salah satunya adalah dengan memperdengarkan musik lembut di tempat kerja. Menurut Gunawan (2006) musik merupakan satu aspek penting dalam hidup manusia dan respon kita terhadap musik sudah terukir dalam otak sejak lahir. Menurut pemerhati musik Nanok Triyono (dalam Musbikin, 2009) menyatakan bahwa kinerja otak yang terlalu berat atau yang dapat menimbulkan rasa penat akan berujung pada kondisi pikiran dan emosi yang labil. Selanjutnya dikatakan oleh Musbikin bahwa fungsi musik dalam situasi ini adalah memberikan stimulus untuk meringankan atau menyegarkan kinerja otak Porter dan Hernacki (2013) menjelaskan pada saat otak kiri sedang bekerja, seperti mempelajari materi baru, otak kanan tidak bekerja dan cenderungmengganggu kerja otak kiri sehingga membuat seseorang melamun dan tidak dapat berkonsentrasi. Salah satu cara untuk menyibukkan kerja otak kanan agar tidak mengganggu kerja otak kiri adalah dengan memperdengarkan alunan musik. Selain itu, Direktur Cognitive Studies di Norapa Institute di Boulder dan penulis The Brain's Timetablle for Developing Musikal Skills menyarankan musik instrumental untuk mengoptimalkan kreatifitas.

Menurut Djohan (2009) terapi musik berperan sebagai salah satu teknik relaksasi untuk memperbaiki, memelihara, mengembangkan mental dan fisik, serta 
kesehatan emosi. Suasana hati yang disebabkan oleh musik dapat merubah konsentrasi, persepsi dan memori serta mempengaruhi keputusan seseorang terhadap kondisi mental dan emosionalnya (Djohan, 2009). Musik secara umum mampu membantu seseorang untuk meningkatkan konsentrasi, menenangkan pikiran, musik membentuk nuansa ketenangan dan membantu seseorang melakukan relaksasi. Terapi musik secara khusus sangat efektif dalam 3 bidang pengobatan yaitu: (1) sakit, kecemasan, dan depresi, (2) cacat mental, emosi, dan fisik, (3) Gangguan neurologis (Djohan, 2009). Musik berkaitan dengan emosi, karena pencipta aransemen musik menciptakan dengan melibatkan emosi yang dimilikinya. Vibrasi yang dihasilkan oleh musik mempengaruhi individu secara fisik, sedangkan harmoni yang dihasilkan akan mempengaruhi secara psikis. Jika vibrasi dan harmoni musik yang digunakan tepat, pendengar akan merasa nyaman dan tenang, sehingga metabolisme dalam tubuh akan berfungsi maksimal dan stres pada seseorang akan berkurang (Satiadarma, 2004).

Menurut Campbell (2001) musik memiliki beberapa manfaat, seperti menutupi bunyi dan perasaan yang tidak menyenangkan, memperlambat dan menyeimbangkan gelombang otak, mempengaruhi pernapasan, musik mengurangi ketegangan otot dan memperbaiki gerak serta koordinasi tubuh, musik juga mempengaruhi suhu badan, musik dapat mengatur hormon- hormon yang berkaitan dengan stres, musik dapat memperkuat ingatan dan pelajaran, musik dapat meningkatkan produktivitas, musik dapat meningkatkan asmara dan seksualitas, musik dapat merangsang pencernaan, musik meningkatkan daya tahan, musik meningkatkan penerimaan tak sadar terhadap simbolisme, dan musik dapat menimbulkan rasa aman dan sejahtera.

Menurut Gunawan (2006) musik yang digunakan untuk mengiringi kerja pada umumnya adalah musik ringan yang dimainkan dengan instrument saja. Musik instrumental mampu menaikkan semangat seseorang (mood menjadi baik) dan memberi ketenangan bagi indera pendengaran, dimana musik dengan denyut kurang lebih 60 ketukan per menit dapat mengubah kesadaran dari beta menuju kisaran alfa. Ketenangan dan kesadaran yang meningkat dicirikan oleh gelombang alfa yang daurnya mulai 8 hingga 13 hertz, (Campbell 2001).

Pada kondisi ini, otak memproduksi hormon serotonin dan endorfin yang menyebabkan seseorang merasakan rasa nyaman, tenang, bahagia, hormon ini membuat imuntubuh meningkat, pembuluh darah terbuka lebar, detak jantung menjadi stabil, dan kapasitas indra sesorang meningkat (Sentanu, 2007). Selanjutnya dikatakan oleh Campbell dengan mendengarkan musik yang bunyinya lebih panjang dan lebih lambat, mampu memperdalam dan memperlambat pernafasan sehingga memungkinkan pikiran menjadi tenang. Dengan kondisi yang demikian dapat menurunkan keinginan individu untuk mengobrol pada saat bekerja. Jika mengacu pada teori Campbell, hasil penelitian pada jurnal tentang terapi musik kejien yang dapat menurunkan tingkat stress, kecemasan bahkan depresi dikarenakan terapi tersebut menggunakan musik bertempo pelan. Hasil temuan kedua yang membuktikan bahwa terapi musik Mozart tidak dapat menurunkan tingkat stress, kecemasan atau depresi diasumsikan karena menggunakan tempo yang berbeda yaitu lebih cepat 
daripada tempo musik kejien, mengingat bahwa musik Mozart memiliki beragam jenis tempo. Namun hal ini masih menjadi asumsi penulis, dikarenakan peneliti pada jurnal tersebut tidak mencantumkan tempo musik yang di gunakan untuk terapi.

\section{Hasil Analisis Faktor-Faktor Yang Berpengaruh Pada Kondisi Burnout Individu}

Pada jurnal yang berjudul "Regulasi Diri dengan Burnout pada Guru" menghasilkan temuan bahwa regulasi diri yang baik pada individu akan membuatnya mampu mengatasi stres dan emosi, karena individu tersebut akan dapat mengontrol dan mengarahkan dirinya untuk mencapai tujuan yang diinginkan.

Pada jurnal yang berjudul "Burnout Perawat Perempuan Ditinjau Dari Iklim Organisasi" membuktikan bahwa ada hubungan negatif antara persepsi terhadap iklim organisasi dengan burnout, yang berarti bahwa semakin memiliki persepsi yang positif terkait iklim organisasi Rumah Sakit tempat mereka bekerja, maka semakin rendah kecenderungan perawat mengalami burnout, dan sebaliknya. Faktor personal (misalnya usia, kepribadian, dan kompetensi), dan faktor sosial (misalnya konflik antara pribadi dengan pimpinan atau kelompok kerja, dan atau adanya masalahmasalah keluarga) menjadi faktor-faktor yang mempengaruhi burnout.

Pada jurnal yang berjudul "Kebersyukuran dan Burnout pada Guru Sekolah Dasar di Yogyakarta menghasilkan temuan bahwa semakin tinggi kebersyukuran guru maka semakin rendah burnout yang dialami guru tersebut. Dengan bersyukur, memungkinkan guru untuk mengurangi fokus guru terhadap masalah yang dialami dalam pekerjaannya. Ketika seorang guru memiliki tingkat kebersyukuran yang tinggi, akan menimbulkan emosi positif pada guru sehingga guru cenderung akan berfokus pada aspek-aspek yang dapat mendorong penyelesaian pekerjaannya menjadi lebih baik dibandingkan melihat aspek yang cenderung negatif.

Pada jurnal yang berjudul "Hubungan Efikasi Diri Dan Dukungan Sosial Dengan Burnout Pada Perawat" menghasilkan temuan bahwa hubungan efikasi diri dan burnout pada perawat di penelitian ini tidak terbukti atau ditolak, artinya tinggi rendahnya efikasi diri yang dimiliki seorang perawat tidak mutlak berpengaruh pada terjadinya burnout pada perawat. Temuan ini memperjelas bahwa kriteria burnout disebut rendah apabila aspek emotional exhaustion dan dipersonalisasi rendah dan aspek personal accomplishment tinggi, serta temuan lainnya yaitu tinggi rendahnya dukungan sosial yang diperoleh perawat tidak berpengaruh pada burnout.

Pada jurnal yang berjudul "Hubungan Antara Stress Kerja Dan Motivasi Kerja Dengan Kinerja Karyawan" menghasilkan temuan bahwa ada hubungan positif yang sangat signifikan antara stress kerja dan motivasi kerja dengan kinerja karyawan, dan tidak ada hubungan yang signifikan antara motivasi Kerja dengan kinerja karyawan.

Pada jurnal yang berjudul "Pengaruh Burnout dan Employee Engagement terhadap Intensi Turnover Karyawan Hotel" membuktikan bahwa terdapat pengaruh positif burnout terhadap intensi turnover karyawan di Hotel X Group. Kemudian, terdapat pengaruh negatif employee engagement terhadap intensi turnover karyawan di Hotel X 
Group. Serta adanya pengaruh burnout dan employee engagement terhadap intensi turnover karyawan di Hotel X Group. Sehingga dapat dikatakan bahwa semakin seseorang merasakan burnout, maka intensi turnover karyawan semakin tinggi.

Pada jurnal yang berjudul "Hubungan antara Self-efficacy dengan Burnout Pada Pengajar Taman Kanak-Kanak Sekolah "X" di Jakarta" membuktikan bahwa terdapat hubungan negatif yang signifikan antara self-efficacy dengan burnout pada pengajar TK sekolah " $\mathrm{X}$ " di Jakarta. Hal ini mengandung pengertian semakin tinggi selfefficacy maka semakin rendah burnout pada pengajar TK sekolah " $\mathrm{X}$ " begitu juga semakin rendah self-efficacy maka semakin tinggi burnout pada pengajar TK sekolah "X" dan self-efficacy memberikan kontribusi terhadap burnout pada pengajar TK di sekolah "X" sebesar 47,7\%

Pada jurnal yang berjudul "Burnout dan Dimensi Kepribadian Conscientiousness" menghasilkan temuan bahwa burnout dan kepribadian conscientiousness secara bersama-sama dapat berperan terhadap performansi kerja. Semakin tinggi burnout yang dirasakan tidak kemudian otomatis berdampak negatif terhadap kehidupan kerja karyawan apabila ada interaksi bersamaan dengan kepribadian conscientiousness yang merupakan filter atau penahan dampak negatif dari burnout yang dirasakan. Dengan demikin burnout tidak selalu memunculkan dampak negatif jika ada faktor internal individu yang menyertainya. Individu yang memiliki level conscientiousness yang tinggi menunjukkan perilaku yang terorganisir, dapat diandalkan, pekerja keras, memiliki disiplin diri, tepat waktu, cermat, rapi, tekun dan berambisi.

Pada jurnal yang berjudul berjudul "Life stress and academic burnout" memiliki hasil temuan bahwa tingkat burnout dan life-stress mahasiswa secara umum tidak sama. Adanya perbedaan burnout akademik dan life-stress di antara jenis kelamin yang berbeda dan tahun yang berbeda ditemukan, dan secara keseluruhan, melaporkan "future development stress" menjadi yang terbesar, yang menunjukkan bahwa mahasiswa mengkhawatirkan masa depan mereka. Penelitian tersebut menemukan bahwa "self- identity stress", "interpersonal stress", "future development stress", dan "academic stress" dapat memprediksi burnout akademik. Namun family stress dan stres emosional bukan merupakan prediktor yang signifikan secara statistik dari burnout akademik. Hal tersebut menjelaskan mengapa kelelahan akademik hanya berkorelasi dengan empat jenis stres saja, namun tekanan hidup dalam bentuk apapun juga dapat menyebabkan kelelahan akademis. Penelitian telah menunjukkan korelasi yang signifikan antara life stress dan burnout akademik di perkuliahan (Huang dan Lin, 2010). Beberapa faktor stres akan membuat mahasiswa burnout, karena ketidakmampuannya mengatasinya life stress (tekanan hidup) tertentu.

\section{Kesimpulan}

Kondisi burnout individu dapat dipengaruhi dari berbagai faktor seperti regulasi diri, iklim organisasi, kebersyukuran, self-efficacy, stress kerja, employee engagement, dimensi kepribadian conscientiousness life stress dan academic stress, dan yang lain. Burnout syndrome dapat menyerang siapa saja, tidak hanya dosen, 
tetapi juga karyawan, perawat bahkan mahasiswa. Persepsi individu terkait beban kerja yang dihadapinya juga merupakan faktor yang dapat mempengaruhi resiko terjadinya burnout, sehingga tidak dapat dibandingkan antara pekerjaan yang satu dengan yang lain, namun pada beberapa profesi tertentu terutama yang langsung berkaitan dengan publik, memiliki kerentanan yang lebih besar untuk terjadi burnout. Burnout merupakan bentuk dari stress yang berkepanjangan dan tidak ditangani. Oleh karena itu, diperlukan intervensi dan salah satu bentuk intervensinya adalah melalui terapi musik.

Musik yang digunakan sebagai terapi burnout memiliki spesifikasi tertentu seperti tempo yang lambat, harmoni yang tenang, tidak memiliki lirik atau dengan kata lain adalah musik instrumental. Pemberian terapi musik ini dapat dilakukan secara bersama sama di dalam ruang kerja, maupun secara individual menggunakan mp3 dari handphone masing-masing. Terapi musik disini, hanya membantu menurunkan tingkat burnout atau stress, tetapi tidak benar benar menyembuhkan, karena itu bila kondisi burnout berada pada tingkat sedang sampai tinggi disarankan untuk meminta bantuan ahli profesional seperti psikolog atau psikiater. 


\section{BIBLIOGRAFI}

Anastasi, A. (1990). Psychological Testing (6th Ed). New York: Mac Millan PublishingCompany. Google Scholar

Badra, I.W. Hubungan antara Stres dan Motivasi dengan Kinerja Dosen Tetap pada Akper Sorong. Tesis. Program Pascasarjana IKM Universitas Gadjah Mada. 2004 Google Scholar

Baron, R.M. \& Kenny, D.A. 1986. The Moderator-Mediator Variable Distinction in Social Psychological Research: Conceptual, Strategic, and Statistical Considerations. Journal of personality and Social Psychology. 51 (6), 11731182 Google Scholar

Campbell, D. (2001). The Mozart Effect. Jakarta : Gramedia Pustaka Utama. Diterjemahkan : Drs.T. Hermaya Google Scholar

Cahyolaksono, S. M. (2008). Stress Kerja pada Dosen Perempuan Ditinjau dari Konflik Peran Ganda dan Dukungan Sosial Suami. Skripsi Mahasiswa Fakultas Psikologi Universitas Katolik Soegijapranata Semarang Google Scholar Djohan. 2005. Psikologi Musik. Editor: A. Supratiknya. Yogyakarta: Buku Baik Google Scholar

Djohan. (2006). Terapi musik, teori dan aplikasi. Yogyakarta: Galangpress. Google Scholar

Djohan. 2009. Psikologi Musik. Yogyakarta: Penerbit Best Publisher Google Scholar

Hakanen, J. J., Bakker, A. B., \& Schaufeli, W. B. 2006. Burnout and work engagement among teachers. Journal of School Psychology, 43, 495-513. Google Scholar

Kemper K.J., \& Danhauer,S.C. (2005). Music as Therapy. Southern Medical Association.282-286. Google Scholar

Kreitner, Robert and Angelo Kinichi. 2004. Organization Behavior. Sixth Edition.The McGraw-Hill Companies Inc. New York. Google Scholar

Labbe, E., Schmidt, N., Babin, J., \& Pharr, M. (2007). Coping with stress: the effectiveness of different types of music. Appl psychophysiol biofeedback, 32, 163-168. doi: 10.1007/s10484-007-9043-9. Google Scholar

Leiter, M. P., \& Maslach, C. (1988). The impact of interpersonal environment of burnout and organization commitment. Journal of Organizational Behavior, 9, 297-308. Google Scholar

Leiter, M. P., \& Maslach, C. (2004). Areas of worklife: A structured approach to organizational predictors of job burnout. In P. L. Perrewé \& D. C. Ganster (Eds.), Research in occupational stress and well being: Vol. 3. Emotional and physiological processes and positive intervention strategies (pp. 91-134). US: Elsevier Science/JAI Press. Google Scholar

Leiter \& Maslach, C. (2005). Banishing burnout: six strategies for improving your relationship with work. USA: Jossey Bass Google Scholar

Maslach, C. dan Jackson, S. E. 1981.The measurement of experienced burnout. 
Studi Literatur Pengaruh Musik InstrumentalterhadapKondisi Burnout Syndrome

Journal Of Occupational Behaviour. Vol. 2.99-113 (1981) Google Scholar

Maslach C., \& Jackson, S.E. (1986). Maslach Burnout Inventory (2nd ed.). Palo Alto. CA:Consulting Psychologists Press. Google Scholar

Maslach, C. and Leiter, M.P. 1997. The Truth about Burnout: How Organizations Cause Personal Stress and What to Do About It, Jossey-Bass, San Francisco, CA. Google Scholar

Maslach, C., Schaufeli, W. B., Leiter, M. P. (2001). Job Burnout. Annu. Rev. Psychol. 2001.52:397-422 Google Scholar

Musbikin, I. 2009. Kehebatan Musik Untuk Mengasah Kecerdasan Anak. Jogjakarta: PowerBooks (Ihdina) Google Scholar

Safaria, T. Peran Religious Coping Sebagai Moderator dari Job Insecurity terhadap StresKerja pada Staf Akademik. Humanitas. 2011. VIII, pp.155-170.

UU No. 14 tahun 2005 tentang Guru dan Dosen Google Scholar

Wayanti, S., Suryaningsig \& Esyuananik. (2016). Kelelahan Kerja Bornout Sydrom Pada Dosen Berdasarkan Karaketeristik Demografi, Harapan, Penghargaan Dan Kontrol. Jurnal Penelitian Kesehatan Suara Forikes. 7(1).39-45. Google Scholar

Winefield, A.H., Con, N.G., Stough., Dua, J., \& Hapuararchchi, J. Occupational Stress in Australian Google Scholar

First publication right:

Jurnal Syntax Fusion: Jurnal Nasional Indonesia

This article is licensed under:

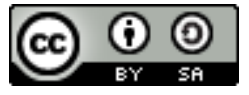

